\title{
PENEGAKAN HAK ASASI MANUSIA DI MASA TRANSISI DEMOKRASI: KASUS AFRIKA SELATAN DAN INDONESIA
}

\author{
Anwar Ilmar \\ Universitas 17 Agustus 1945 Jakarta, Jakarta, Indonesia \\ anwar.ilmar@gmail.com
}

\begin{abstract}
This research would like to analyze the human rights promotion during the democratic transition period in South Africa and Indonesia. The common phenomenon that happened during the transition period from authoritarian regime into democratic regime, is when the society were demanding the authoritarian regime to be responsible for their power abuses in the past. The power abuses refer to the human rights violations. Therefore it became the challenge for the new regime to articulate the people's demand into political policies as a form of transitional justice.

This research aimed to compare the political policies and transitional justice process between Indonesia and South Africa. The transition period happened in South Africa in 1990s when the apartheid regime ended, while in Indonesia was the collapse of the Soeharto's regime in 1998. This paper used system and structural theory to analyze political process for arrangement and implementation of transitional justice for both countries. Research method used in this paper was qualitative research with comparative description as an analytical technic. Data gathering technic was done through literature review on related books.

This research concluded the idea of human rights promotions in South Africa and Indonesia have several similarities, such as the establishment of human rights body named Komisi Kebenaran dan Rekonsiliasi (Truth and Reconciliation Commission). However on the other side, there was contrast difference regarding the role of the authoritarian elites in transitional period. Authoritarian elites in South Africa still had role in the political system and structure in giving support toward the establishment of transitional justice. In contrast, the authoritarian elites in Indonesia controlled the political system and structure to hamper the establishment of transitional justice.
\end{abstract}

\section{Keywords; Democracy, Human Rights, Transitional Justice}

\begin{abstract}
Abstrak
Penelitian ini hendak mengkaji tentang penegakan Hak Asasi Manusia di masa transisi demokrasi di Afrika Selatan dan Indonesia. Fenomena yang lazim terjadi pada era transisi dari rezim otoriter menuju rezim demokrasi yakni adanya tuntutan rakyat yang meminta pertanggungjawaban dari rezim otoriter atas praktik penyalahgunaan kekuasan negara di masa lalu. Apalagi hal tersebut menyangkut kejahatan kemanusiaan berupa pelanggaran Hak Asasi Manusia. Selanjutnya menjadi tantangan rezim di masa transisi untuk mengartikulasikan tuntutan tersebut dalam bentuk kebijakan politik sebagai wujud dari pelaksanaan keadilan transisional (transitional justice).

Penelitian ini bertujuan untuk membandingkan kebijakan politik dan proses pelaksanaan keadilan transisional dua negara yang tengah dalam transisi politik dari rezim otoriter menuju demokrasi, yakni Afrika Selatan sejak berakhirnya rezim apartheid awal tahun 1990-an dan Indonesia sejak jatuhnya rezim Soeharto tahun 1998. Penelitian ini menggunakan teori sistem dan struktural untuk menganalisa proses politik perumusan
\end{abstract}


dan pelaksanaan keadilan transisional di kedua negara. Metode penelitian yang digunakan dalam penelitian ini adalah penelitian kualitatif dengan teknik analisa komparatif desktiptif. Teknik pengumpulan data dilakukan melalui telaah pustaka terhadap bukubuku yang berkaitan dengan topik penelitian ini.

Penelitian ini menyimpulkan bahwa gagasan mengenai penegakan hak asasi manusia di Afrika Selatan dan Indonesia memiliki beberapa persamaan seperti pembentukan wadah melalui Komisi Kebenaran dan Rekonsiliasi. Namun di sisi lain terdapat perbedaan yang cukup kontras terkait peran elit rezim otoriter di masa transisi. Elit otoriter di Afrika Selatan yang masih berperan dalam sistem dan struktur politik memberikan dukungan terhadap proses penegakan keadilan transisional. Sebaliknya, di Indonesia elit otoriter yang masih menguasai sistem dan struktur politik terkesan menghambat proses penegakan keadilan transisional.

Kata Kunci; Demokrasi, Hak Asasi Manusia, Keadilan Transisional 


\section{Pendahuluan}

Huntington (1995) mencatat sejak tahun 1974 hingga periode 1990-an merupakan momentum gelombang demokratisasi ketiga yang melanda dunia. Gelombang demokratisasi tersebut sekaligus mengakhiri berbagai rezim otoriter hampir di seluruh belahan dunia. Momen terbesarnya adalah runtuhnya Uni Sovyet yang bertahan hampir seabad lamanya. Arus demokratisasi tersebut diperkuat lagi dengan tesisnya Fukuyama (1992) tentang kemenangan liberalisme politik dan ekonomi yang menjadi akhir dari sejarah. Maka tanpa bermaksud meniadakan rezim otoriter yang masih eksis, dapat dikatakan bahwa demokrasi telah menjadi role model-nya rezim politik dunia menjelang dan memasuki abad 21.

Pada negara-negara otoriter, terdapat berbagai bentuk penyelewengan kekuasaan seperti pemilu yang dikontrol, tidak adanya checks and balances antar lembaga kekuasaan, rule of law yang dikooptasi, kebijakan yang sentralistik, korupsi, kolusi, nepotisme, dan lain sebagainya. Disamping itu juga, hal yang paling mencolok adalah betapa kuatnya represifitas negara untuk mengekang hak-hak sipil dan politik warga negara. Pada tiap negara otoriter, bentuk-bentuk kekuasaan represifnya berbeda-beda, namun penggunaan instrumen kekerasan dalam mengekang hak-hak sipil dan politik menjadi hal yang umum terjadi di seluruh rezim otoriter.

Afrika Selatan dan Indonesia, merupakan dua contoh negara yang memiliki pengalaman dibawah rezim otoriter sebelum mengalami proses transisi menuju demokrasi. Dalam kasus Afrika Selatan, rezim otoriter merupakan konstruksi politik kolonialisme dalam bentuk dominasi kelompok atau ras tertentu dan dominasi ini berlanjut atau berusaha dipertahankan oleh kelompok tersebut dengan berbagai cara dalam sistem politik baru pasca kemerdekaan. Sistem politik ini dikenal dengan politik apartheid. 
Penganiayaan, pengusiran, pemerkosaan, pembunuhan merupakan serangkaian bentuk kekerasan yang dialami oleh mayoritas warga kulit hitam di Afrika Selatan. Serangkaian kekerasan tersebut diakhiri dengan berbagai tekanan dari dunia internasional dan terus menguatnya gerakan-gerakan politik dalam negeri Afrika Selatan. Sehingga pada masa pemerintahan F.W. de Klerk dirumuskan kebijakan yang revolusioner dengan dicabutnya larangan aktivitas African National Congress (ANC) sebagai partai politik dan pemulihan hak politik warga kulit hitam.

Hampir serupa dengan apa yang dialami oleh Afrika Selatan dibawah rezim apartheid, represifitas kekuasaan dengan cara-cara kekerasan juga dijadikan sebagai instrumen rezim otoriter Soeharto untuk mengekang hak-hak warga di Indonesia. Demi stabilitas politik untuk mendukung proyek pembangunan, Soeharto mengkonsolidasikan kekuasaannya dengan memusatkan kontrolnya pada struktur politik otoriter yang didominasi oleh militer. Kekerasan rezim Soeharto dimulai saat Soeharto meraih kekuasaan pada 1965, dimana terjadi penahanan, penganiayaan, penghilangan, dan pembunuhan terhadap jutaan orang di berbagai daerah (Birks, 2006:25-27). Berbagai peristiwa kekerasan lainnya turut mewarnai otoritarianisme rezim Soeharto diantaranya peristiwa Tanjung Priok, Timor Timur, Aceh, Irian Jaya, tragedi 27 Juli 1996, tradegi semanggi dan trisakti, dan masih banyak kasus kekerasan lainnya.

Namun berbeda dengan Afrika Selatan, di Indonesia, proses transisi rezim otoriter dipicu oleh krisis ekonomi yang melanda Indonesia di penghujung tahun 1997 sampai 1998 serta ditambah dengan protes-protes dari gerakan mahasiswa dan gerakan rakyat lainnya yang mengakibatkan sebagian besar aktor dalam elit otoriter meninggalkan Soeharto dan mendesak Soeharto untuk mengundurkan diri. Baik Afrika Selatan maupun Indonesia, pada masa transisi memilih demokrasi sebagai landasan sistem politik kedua negara tersebut. Demokrasi dipandang sebagai antitesis 
dari rezim otoriter dimana dalam demokrasi pemerintahan rakyat dilandasi oleh kontrol masyarakat dan adanya kesetaraan politik (Uhlin, 1998:1).

Upaya penegakan Hak Asasi Manusia (HAM) menjadi tuntutan prioritas di era transisi, terutama menyangkut berbagai pelanggaran HAM di masa lalu. Hal ini dipandang banyak kalangan pegiat HAM sangat memengaruhi proses transisi demokrasi yang berkemajuan sebagai wujud pelaksanaan keadilan transisional.

Dalam konteks ini, dibutuhkan suatu formula kebijakan yang tepat dan efektif khususnya ketika kekerasan terjadi di berbagai tempat dan melibatkan kelompokkelompok yang masih mempunyai akses terhadap kekuasaan militer atau sipil. Masalah ini sangat penting karena penegakan keadilan di masa transisi lebih dari sekadar menangani pelanggaran HAM, melainkan juga dapat menjadi suatu dasar moral sebuah reformasi yang menjunjung tinggi kemanusiaan melalui proses yang demokratis, tanpa kekerasan, dan menjunjung tinggi supremasi hukum.

Masalah inilah yang dihadapi oleh Afrika Selatan dan Indonesia pada masa transisi demokrasi. Kedua negara juga didesak untuk merumuskan suatu kebijakan yang dapat mengungkap pelanggaran HAM yang terjadi pada masa rezim sebelumnya, sebagai sebuah wujud tindakan nyata penegakan HAM di masa transisi demokrasi.

\section{Demokrasi, Hak Asasi Manusia, dan Keadilan Transisional}

Merkel dalam Uhlin melihat bahwa demokrasi adalah konsep yang multidimensional yang melembagakan tiga dimensi kekuasaan politik. Konsep demokrasi yang abstrak tersebut di-derivasi ke dalam suatu bagian-bagian rezim sebagai tolak ukur bagi semua negara perbandingan demokrasi dalam penelitian demokratisasi. Konsep tersebut dikenal dengan demokrasi negara hukum yang terdiri dari lima bagian rezim, antara lain; rezim pemilihan demokratis, hak-hak partisipasi 
politik, hak kebebasan sipil, kontrol kekuasaan horizontal, dan otoritas pemerintahan yang efektif (Merkel dalam Uhlin, 1998:22-25).

Dalam kajian ini, penekanan konseptualisasi lebih kepada korelasi demokrasi dengan Hak Asasi Manusia (HAM) melalui hak kebebasan sipil. Kebebasan sipil menggambarkan elemen sentral dari dimensi demokrasi negara hukum. Hak-hak tersebut berupa perlindungan individu negara yang dijamin dalam setiap kebijakan negara. Sehingga hak-hak kebebasan ini dapat menciptakan syarat-syarat dasar terbentuknya negara hukum. Juga jaminan untuk tidak terjadinya penahanan yang tidak legal, bebas dari penganiayaan dan pengusiran, dan persamaan perlakuan di depan hukum.

Dalam masa transisi ${ }^{1}$, demokrasi dilihat sebagai proses pengefektifan hak-hak tertentu yang melindungi individu maupun kelompok sosial dari tindakan sewenangwenang atau ilegal yang dilakukan oleh negara atau pihak ketiga. Transisi tersebut ditandai dengan perubahan norma dan prinsip yang dianut oleh negara. Transisi semacam ini mulai terjadi ketika para pemimpin otoriter mulai memodifikasi pemerintahan mereka ke arah yang memberikan lebih banyak jaminan pasti bagi hakhak individu dan kelompok (O’Donnell, Schmitter, Whitehead, 1993:7).

Pandangan tersebut sesungguhnya berfokus pada tataran elit politik dan menganalisis transisi rezim sebagai negosiasi antara elit otoriter dengan oposisi moderat. Dalam masa transisi demokrasi tersebut, pengefektifan hak-hak juga dimaknai sebagai tuntutan keadilan atas pengekangan hak-hak di masa rezim otoriter. Respon terhadap pemerintahan yang represif memiliki arti ketaatan terhadap kedaulatan hukum. Sementara suatu negara mengalami perubahan politik, peninggalan-peninggalan ketidakadilan di masa lalu menentukan apa yang bisa

\footnotetext{
${ }^{1}$ Transisi adalah interval (selang waktu) antara satu rezim politik dan rejim yang lain. Transisi dibatasi oleh dimulainya proses perpecahan rezim otoriterian oleh pengesahan beberapa bentuk demokrasi, kembalinya beberapa bentuk pemerintahan otoriter atau kemunculan beberapa suatu alternatif revolusioner (O’Donnell, Schmitter, Whitehead, 1993).
} 
dianggap transformatif (Teitel, 2004:15). Bertolak dari hal tersebut lahir konsepsi mengenai keadilan transisional (transitional justice).

Pengertian mengenai konsep keadilan transisional sebetulnya masih menjadi perdebatan yang hangat di kalangan akademisi maupun praktisi HAM. Perdebatan tersebut dilontarkan oleh Enny Soeprapto dalam beberapa pertanyaan seperti;

"apakah keadilan transisional merupakan suatu upaya penegakan keadilan di masa tertentu, dalam hal ini masa transisi?; ataukah keadilan transisional merupakan suatu teori atau konsep baru disamping konsep keadilan yang sudah ada sebelumnya?; jika dipandang sebagai suatu teori, apakah berarti merupakan keadilan yang sedang mengalami transisi atau upaya penegakan keadilan di masa transisi? Namun terdapat pandangan umum bahwa, keadilan transisional adalah suatu upaya perwujudan tuntutan keadilan rakyat atas pelanggaran HAM masa lalu oleh rezim otoriter di masa transisi yang menjadi tanggung jawab negara (Soeprapto, 2009)."

Karena peristiwanya terjadi di masa lalu, untuk menegakkan keadilan tersebut biasanya dilaksanakan melalui mekanisme yang cukup beragam. Diantaranya yang menjadi mekanisme dasar dari keadilan transisional adalah: a) pengungkapan kebenaran $^{2}$ dan rekonsiliasi ${ }^{3}$; b) proses peradilan; c) Reparasi; d) Reformasi sektor keamanan,dan lain sebagainya (ICTJ dan Kontras, 2011).

Pilihan atas mekanisme tersebut tergantung pada kebijakan tiap-tiap negara. Dalam hal ini, sistem politik memiliki pengaruh yang signifikan terhadap efektifitas

\footnotetext{
${ }^{2}$ Hayner (2001) mengutip definisi dari Habermas mengatakan bahwa kebenaran kita sadari dalam tiga aspek. Pertama, kebenaran bersifat faktual, berkaitan dengan sesuatu yang benar-benar terjadi atau ada. Kedua, kebenaran bersifat normatif, berkaitan dengan apa yang kita rasakan adil atau tidak. Jadi seorang pelaku genocide benar-benar seorang penjahat, karena kita mengutuk perbuatan tersebut. Ketiga, kebenaran hanya akan menjadi kebenaran bila dinyatakan dengan cara yang benar. Jika kita menyampaikan kebenaran, namun tampak bahwa kita sebetulnya tidak sungguh-sungguh yakin dengan apa yang telah kita katakan, itu bukanlah kebenaran yang sesungguhnya.

3 Sebelumnya, kata rekonsiliasi sangat diwarnai oleh wacana Judo-Kristen. Dewasa ini, kata rekonsiliasi lebih bermakna psikologi sosial-politik. Rekonsiliasi berarti kesediaan untuk memaafkan atau melupakan demi penciptaan tatanan politik yang demokratis di masa depan. Singkatnya, rekonsiliasi lebih menekankan pada pencapaian tujuan akhir itu, yaitu stabilitas tatanan demokrasi, ketimbang mengutamakan penuntutan pidana (Bronkhorst, 2001:36-37).
} 
kebijakan keadilan transisional. Demokratis atau tidaknya suatu sistem politik dapat dilihat dari peran dari unit-unit sistem atau struktur politik yang bekerja. Hambatan sistem atau struktural seringkali menjadi problem mendasar mengapa suatu negara cenderung tidak demokratis.

\section{Analisa Sistem dan Struktural}

David Easton dalam Chilcote menolak konsep tentang negara dalam pendekatan studi politik karena membingungkan. Sistem baginya memungkinkan kejelasan konseptualisasi. Demikian pula kekuasaan dipahami hanya sebagai satu dari banyak konsep signifikan yang berguna bagi studi kehidupan politik. Konsep-konsep kekuasaan, pengambilan keputusan, kewenangan, dan kebijakan adalah yang menjadi esensi dalam gagasan kehidupan politik Easton sebagaimana alokasi-alokasi nilainilai kewenangan dalam masyarakat. Menurut Easton, yang menjadi ciri sistem antara lain; 1) sifat-sifat identifikasi dalam bentuk unit dan batas-batas; 2) input dan output; 3) pembedaan di dalam sistem; 4) integrasi di dalam sistem (Easton dalam Chilcote, 1981:148).

Almond mengajukan suatu formulasi baru, memanfaatkan sistem politik sebagai satu basis dan pijakan menuju sekumpulan konsep yang berhubungan dengan struktur dan fungsi. Almond mengajukan tesis bahwa sistem politik memiliki ciri-ciri universal dan bahwa demi tujuan-tujuan teori dan analisis, ciri-ciri tersebut dapat dikonseptualisasikan ke dalam skematik studi perbandingan politik. Ciri-ciri tersebut antara lain; 1) semua sistem politik memiliki struktur politik; 2) fungsi-fungsi yang sama muncul dalam seluruh sistem politik; 3) seluruh struktur politik adalah multifungsional dan; 4) seluruh sistem politik bercampur dengan pengertian budaya (Almond dalam Chilcote, 1981:168).

Kerangka kerja dasar sistem politik Easton didefinisikan oleh tindakan yang berhubungan dengan keputusan-keputusan mengikat suatu masyarakat. Unit-unit 
sistem politik adalah tindakan-tindakan politik. Input dalam bentuk permintaan dan dukungan menjadi masukan sistem politik. Sedangkan dukungan adalah tindakan atau orientasi yang mendorong dan menahan suatu sistem politik. Selanjutnya output berasal dari sistem politik dalam bentuk keputusan dan tindakan politik. Ini kemudian menjadi umpan balik bagi lingkungan lewat pemuasan permintaan sebagian anggota sistem, dan dengan demikian mereka membangkitkan dukungan terhadap sistem. Mungkin juga terdapat akibat-akibat negatif yang menghasilkan permintaanpermintaan baru kepada sistem (Easton dalam Chilcote, 1981:148).

Almond sebagian dipengaruhi oleh input, output, dan umpan balik dari kerangka kerja Easton tersebut yang mengarahkannya kepada teori fungsional sistemik. Namun menurut Almond kerangka kerja Easton masih terbatas, terlalu dekat dengan model sistem generik dan input dan outputnya yang secara khusus menurutnya mendiskriminasi bidang politik. Maka Almond memisahkan input dan output menurut fungsinya. Fungsi-fungsi tersebut yaitu; fungsi input, meliputi artikulasi kepentingan, agregasi kepentingan, sosialisasi politik, rekruitmen politik, dan komunikasi politik. Fungsi output, meliputi pembuatan kebijakan (policy making), penerapan kebijakan (policy implementation), dan penghakiman kebijakan (policy adjudication). Fungsi politik tersebut dijalankan oleh struktur politik yang didalamnya telah terbentuk diferensiasi struktural dan diikuti dengan spesialisasi fungsi. Bekerjanya struktur politik dalam menjalankan fungsi politik mengikuti rangkaian alur proses politik yang ada (Almond dalam Chilcote:164-165).

Melalui pendekatan analisa sistem dan struktural inilah akan dikaji permasalahan dalam pelaksanaan keadilan transisional di Afrika Selatan dan di Indonesia terkait peran fungsi input, proses, output, dan umpam balik yang dijalankan oleh strukturstruktur politik di kedua negara. 


\section{Kasus Afrika Selatan}

Afrika Selatan melewati masa yang cukup panjang untuk membebaskan diri dari politik apartheid. Mereka harus melewati empat puluh lima tahun pelaksanaan apartheid, dan sekitar tiga puluh tahun perlawanan bersenjata terhadap negara apartheid yang dipelopori oleh African National Congress (ANC). Selama itu, penduduk kulit hitam Afrika Selatan mengalami pembantaian, pembunuhan, penyiksaan, penahanan berkepanjangan dan diskriminasi ekonomi dan sosial yang dilakukan oleh rezim apartheid. Jumlah korban terbesar timbul dalam konflik antara ANC dengan Partai Kemerdekaan Inkatha yang didukung pemerintah, terutama di wilayah timur, KwaZulu Natal (Kasim, 2001:15).

Kemenangan ANC (African Natinonal Congress) dan naiknya Nelson Mandela sebagai Presiden kulit hitam pertama di Afrika Selatan pada Pemilihan Umum 1994 merupakan momentum politik proses transisi menuju demokrasi. Peristiwa politik ini sekaligus mengubur rezim apartheid ke dalam masa lalu bangsa Afrika Selatan. Meski demikian, Pasca rezim apartheid, tuntutan akan keadilan di Afrika Selatan atas penindasan dan pengekangan hak-hak warga kulit hitam di masa lalu merupakan isu utama yang menjadi langkah awal Afrika Selatan dalam melangkah menuju demokrasi, selain melaksanakan mekanisme demokrasi prosedural seperti pemilihan umum. Tuntutan tersebut berupa penghapusan total atas warisan rezim apartheid, dalam konteks ini yang sangat mendapat dorongan adalah upaya pengungkapan kejahatan kemanusiaan pelanggaran HAM yang dialami oleh mayoritas warga kulit hitam Afrika Selatan. Tuntutan tersebut tidak hanya datang dari rakyat Afrika Selatan, namun juga datang dari lingkungan luar terutama dari kelompok-kelompok kepentingan seperti Amnesty International. Tuntutan tersebut menjadi input yang coba diartikulasikan oleh infrastruktur politik yang ada melalui ANC sebagai partai pemenang dalam pemilihan umum dan beberapa organisasi politik lainnya yang menjadi korban rezim apartheid. 
Ketika input berupa tuntutan tersebut masuk kedalam proses sistem politik, sesungguhnya para pengambil kebijakan menyepakati pelaksanaan keadilan transisional agar jalan menuju demokrasi menjadi lebih terang. Akan tetapi, ada sejumlah opsi yang diperdebatkan muncul dalam proses perumusan kebijakannya, terutama dalam hal konsep dan mekanisme pengungkapan pelanggaran HAM di masa lalu tersebut. Elit-elit politik yang berada dalam suprastruktur politik Afrika Selatan di masa transisi, baik di legislatif, eksekutif, dan yudikatif mayoritas merupakan orang-orang yang pernah terlibat dalam rezim apartheid. Akan tetapi sebagaimana dijelaskan oleh O’Donnell dan Schmitter (1986) melihat transisi di Amerika Latin, bahwa proses transisi di Afrika Selatan juga merupakan negosiasi elit rezim apartheid yakni pimpinan De Klerk dan kelompok oposisi moderat yang dipimpin oleh Mandela. Dengan kata lain, bahwa rezim apartheid masih memiliki pengaruh dalam merumuskan kebijakan yang dijalankan pada masa transisi. Hal ini nampak dari peran serta keterlibatan De Klerk bersama Mandela dalam proses peralihan dan mengawal masa transisi menjadi lebih damai.

Dalam pengalaman empiris negara-negara pasca rezim otoriter sesungguhnya opsi untuk mengungkap pelanggaran HAM di masa lalu sangatlah variatif di tiap negara. Mekanisme yang paling populer diterapkan di beberapa negara adalah adalah pengungkapan kebenaran dan rekonsiliasi, terutama merujuk kepada konsep dan mekanisme pengungkapan pelanggaran HAM di Amerika Latin. Begitu juga di Afrika Selatan, kebenaran dan rekonsiliasi merupakan konsep dan mekanisme yang dijadikan landasan dalam perumusan kebijakan dan penerapannya. Berlandaskan pemikiran pada konsep dan mekanisme tersebut, maka pemerintah Afrika Selatan pun membentuk suatu badan atau komisi yang diberi nama Truth and Reconciliation Commision (TRC) atau Komisi Kebenaran dan Rekonsiliasi yang dituangkan dalam Promotion of National Unity and Reconciliation Act 34 of 1995 sebagai output kebijakannya. 
Dalam penerapan kebijakannya selain membuat suatu regulasi, Komisi Kebenaran dan Rekonsiliasi Afrika Selatan telah membentuk sebuah model baru untuk mengungkap kebenaran, dan mampu menghubungkan kebenaran dan pengampunan secara bersama-sama dalam pola yang tidak pernah ada sebelumnya. Komisi itu sendiri memiliki kekuasaan untuk memberikan pengampunan kepada individu-individu yang datang menghadap komisi untuk menceritakan semua yang mereka ketahui tentang kejahatan politik mereka di masa lalu. Seorang peneliti yang juga aktivis HAM, Priscilla B. Hayner, menceritakan bahwa komisi ini telah menjadi pusat perhatian di Afrika Selatan. Hal itu disebabkan karena adanya proses dengar kesaksian (hearing) korban dan pelaku yang dilakukan secara terbuka di hadapan publik. Proses itu diliput secara luas dan terbuka oleh surat kabar dan media massa lainnya, dan lembaga penyiaran menyiarkan secara langsung selama beberapa jam setiap hari, dan bahkan cuplikan dengar kesaksian tersebut juga ditayangkan di televisi pada malam harinya (Hayner, 2001:10).

Melalui peran dari TRC tersebut, pemerintah Afrika Selatan juga berhasil mengimplementasikan kebijakannya secara langsung serta mengkomunikasikannya melalui metode hearing tersebut yang disiarkan dan disaksikan langsung oleh rakyat Afrika Selatan. Sekalipun terdapat resistensi dari para pelaku, dukungan publik terhadap kebijakan tersebut sangat tinggi. Hal tersebut juga tidak terlepas dari peran elit yang memegang suprastruktur politik seperti Mandela dan De Klerk serta Uskup Demond Tutu (TRC) sebagai dua kelompok elit dari rezim yang berbeda yang menggerakkan sistem dengan menjalankan fungsi-fungsinya dengan baik. Dukungan tersebut kemudian menjadi sebuah input baru dalam sistem, yang kemudian merekomendasikan Reformasi UU dan institusi negara yang siap diterapkan pada pemilu 1999, dan pendirian monumen untuk menjaga ingatan serta program reparasi bagi korban, serta adanya prosekusi bagi para pelaku.

\section{Kasus Indonesia}


Di Indonesia, tanpa menafikan peran dari gerakan sosial yang menggeliat pada masa itu, proses transisi dari rezim otoriter Soeharto menuju demokrasi bukan sekedar dihasilkan dari sebuah perubahan sosial radikal yang digerakkan oleh elemen-elemen masyarakat. Mirip dengan proses peralihan di Afrika Selatan, proses transisi yang terjadi juga tidak luput dari peran elit birokrasi dan militer yang meninggalkan Presiden Soeharto dan justru menyarankan agar Soeharto segera melepaskan jabatan presiden yang sudah diembannya selama kurang lebih tiga puluh dua tahun. Bahkan transisi kepemimpinan dari Soeharto ke Habibie yang sebelumnya menjabat sebagai wakil presiden juga tidak dianggap dapat mengubah wajah rezim otoriter ala Soeharto. Hal ini cukup relevan dengan pandangan yang dikemukakan oleh Przeworski bahwa karakteristik dari suatu transformasi rezim, dimana aliansialiansi sering kali goyah secara ekstrim dan kelompok-kelompok dan individuindividu tertentu dapat mengubah posisi mereka seratus delapan puluh derajat (Przeworski, 1993).

Bagaimanapun prosesnya, rakyat Indonesia menjadikan euforia kejatuhan rezim otoriter Soeharto sebagai suatu kemerdekaan atas hak-hak sipil yang selama tiga puluh dua tahun dibelenggu oleh represifitas kekuasaan melalui instrumen birokrasi dan militernya yang membatasi hak-hak sipil dan politik rakyat Indonesia. Wajar saja rakyat Indonesia menyambutnya dengan euforia, sebab, dengan serangkaian peristiwa yang diperankan oleh represifitas rezim Soeharto seperti peristiwa 1965, peristiwa malari, peristiwa talangsari, peristiwa tanjung priok, peristiwa ambon, aceh, tragedi 27 juli 1996, tragedi trisakti, tragedi semanggi, penculikan-penculikan aktivis, dan masih banyak peristiwa atau tragedi lain baik di tingkatan lokal maupun yang berskala nasional menjadi momok sekaligus trauma bagi rakyat Indonesia atas kekejaman rezim otoriter Soeharto. Maka selaras dengan yang terjadi di Afrika Selatan, tuntutan adanya penegakan keadilan atas berbagai 
kejahatan politik dan pelanggaran HAM yang dilakukan rezim otoriter Soeharto itu didorong menjadi input dalam perumusan kebijakan pemerintahan transisional.

Dalam prosesnya, perumusan kebijakan yang dibahas oleh rezim transisi pasca Soeharto juga memperdebatkan berbagai konsep dan mekanisme, dan mengerucut pada model Afrika Selatan dengan membentuk Komisi Kebenaran dan Rekonsiliasi. Namun tidak jelas dari segi struktur dan kewenangannya. Proses pembahasannya di dalam parlemen juga terbilang sangat alot.

Pada tahun 2003, pemerintah dan DPR membahas Rancangan UndangUndang Komisi Kebenaran dan Rekonsiliasi (RUU KKR) di DPR. Pembahasan RUU ini dilakukan DPR dengan membentuk Panitia Khusus (Pansus) yang terdiri dari lima puluh orang dari lintas fraksi. Pembahasan RUU KKR memakan waktu lebih dari satu setengah tahun sebelum akhirnya disahkan menjadi undang-undang pada 7 September 2004, dan menjadi UU No. 27 Tahun 2004 tentang Komisi Kebenaran dan Rekonsiliasi.

Sejauh ini, proses input yang diartikulasikan oleh infrastruktur politik seperti partai politik dan kelompok kepentingan, isu keadilan transisional telah on the right track mengikuti alur sistem yang bermuara pada output kebijakan pemerintah.

Pada mulanya inisiatif tentang KKR tidak dirumuskan dalam sebuah paket kebijakan yang lengkap yang di dalamnya juga menyertakan dimensi perlindungan dan jaminan HAM. Isu tentang KKR merupakan inisiatif para elit politik pada era transisi awal yang disampaikan secara parsial dan kegunaan politiknya yang tidak jelas serta berubah-ubah. Bahkan seperti yang dikemukakan oleh Robertus Robert, dalam penyebutannya sering kali berubah-ubah sedemikain rupa dari "rekonsiliasi" menjadi "rembug nasional", kemudian berubah lagi menjadi "rujuk nasional", lalu kembali ke "rekonsiliasi" lagi. Perubahan-perubahan nama ini mengindikasikan pergeseran dalam konsepsi para inisiatornya masing-masing, yang di dalam hal ini 
jelas-jelas merepresentasikan pandangan dan kepentingan politik yang berbeda-beda satu sama lain (Robert, 2008:97).

Kemudian dalam implementasi kebijakannya, Komisi Kebenaran dan Rekonsiliasi dianggap tidak dapat mewujudkan keadilan transisional yang diharapkan terutama dari perspektif korban yang merasa pelaku lebih diuntungkan. Kasus Indonesia berbeda dengan Afrika Selatan. Di Indonesia, para korban dan kelompok pegiat HAM tidak menghendaki para pelaku kejahatan pelanggaran HAM tersebut mendapatkan pengampunan seperti kasus yang terjadi di Afrika Selatan. Dengan demikian, kebijakan UU No 27 Tahun 2004 belum sempat diimplementasikan dengan membentuk KKR, tetapi sudah mendapat penolakan dari kedua belah pihak baik korban maupun pelaku.

UU No. 27 Tahun 2004 sudah mendapatkan umpan balik berupa gugatan hukum. Dalam konteks ini, kebijakan pemerintah diuji melalui ranah peradilan konstitusi yakni Mahkamah Konstitusi. Kelompok pemohon pertama, terdiri dari korban dan sejumlah organisasi masyarakat sipil, mendalilkan bahwa sejumlah ketentuan UU KKR bertentangan dengan UUD 1945, di antaranya mengenai pemberian pengampunan kepada pelaku, dan penyelesaian pelanggaran HAM masa lalu yang terkesan membiarkan terjadinya transaksi dengan pelaku. Hal ini disinyalir karena adanya prasyarat rekonsiliasi atau penyelesaian pelanggaran HAM dilakukan setelah adanya pengampunan kepada para pelaku.

Sedangkan kelompok kedua, adalah kelompok yang tidak menghendaki adanya Komisi Kebenaran dan Rekonsiliasi, serta penyelesaian berbagai kasus pelanggaran HAM di masa lalu, khususnya terkait dengan penyelesaian kasus seputar peristiwa 1965.

Di luar ekspektasi korban dan kelompok pegiat HAM, MK akhirnya justru membatalkan secara keseluruhan UU KKR tersebut. Dalam konteks ini, kembali kepada teori O'Donnell dan Schmitter bahwa peranan elit rezim otoriter masih 
memiliki pengaruh atau bisa juga telah terjadi negosiasi antara elit berkuasa dari rezim otoriter dengan elit kelompok oposisi terkait dengan pengungkapan kejahatan pelanggaran HAM. Sehingga mengakibatkan beberapa fungsi dalam sistem politik di rezim transisi tidak berjalan dengan baik seperti yang terjadi di Afrika Selatan.

Maka, dari kasus tersebut diatas, dapat diurai mekanisme perumusan kebijakan dalam sistem politik rezim transisi di Afrika Selatan dan Indonesia memiliki karakteristik dan permasalahan yang berbeda. Terlihat bahwa sistem politik di Afrika Selatan berjalan dengan baik meskipun terdapat resistensi kebijakan dari para pelaku pelanggaran HAM. Akan tetapi pemerintah Afrika Selatan berperan penting dalam menerapkan kebijakan melalui mekanisme yang direkomendasikan oleh Truth and Reconciliation (TRC) yakni dengan jalan rekomendasi pengampunan, inisiatif rekonsiliasi, reparasi bagi korban, dan merekomendasikan negara untuk melakukan reformasi legislasi dan institusional sebagai umpan balik dan dukungan terhadap sistem. Elit rezim apartheid memang memiliki peranan penting dalam masa transisi tersebut termasuk dalam pengungkapan pelanggaran HAM. Akan tetapi negosiasi dan kompromi politik yang terjadi antara elit rezim apartheid dan rezim transisi, yakni de Klerk dan Mandela berjalan sinergis terutama dalam memberikan rasionalisasi kepada rakyat. Dengan jargon dari pimpinan TRC uskup Desmond Tutu “tanpa memaafkan tiada hari depan", rakyat Afrika Selatan seolah sepakat untuk menjadikan kebenaran dan rekonsiliasi dengan mengungkap kebenaran melalui pengakuan dan kesaksian jujur dari pelaku dan korban di hadapan jutaan publik Afrika Selatan dan memaafkan sebagai bentuk rekonsiliasi menuju masa depan Afrika Selatan yang menjunjung nilai-nilai Hak Asasi Manusia.

Berbeda dengan Afrika Selatan, di Indonesia, sejak terjadi perumusan kebijakan dalam sistem, fungsi-fungsi politik yang bekerja merumuskan kebijakan dalam sistem tidak memiliki kemampuan responsif atas tuntuan rakyat terutama korban dan kelompok kepentingan. Konsep kebenaran dan rekonsiliasi yang diajukan 
oleh korban dan kelompok kepentingan dinilai tidak sesuai dengan landasan konstitusional UUD 1945 dan kehendak korban. Dalam konteks ini, dapat dilihat negosiasi antara elit rezim otoriter Soeharto dengan elit rezim transisi tidak mampu memberikan rasionalisasi yang dapat diterima oleh semua kalangan sebagaimana yang terjadi di Afrika Selatan atas output kebijakan yang diterapkan. Tidak seperti di Afrika Selatan, rakyat Indonesia terutama korban kejahatan pelanggaran HAM tidak dapat menerima pasal yang memberikan pengampunan bagi para pelaku, serta reparasi yang tidak dapat diterima oleh korban karena dianggap sebagai proses transaksi tawar menawar.

\section{Kesimpulan}

Melalui teori demokrasi, HAM, dan keadilan transisional untuk melihat perumusan serta penerapan keadilan transisional di Afrika Selatan dan Indonesia, dapat dilihat bahwa secara konsep dan teori Indonesia dan Afrika Selatan memiliki banyak kemiripan, namun ketika dilihat dari sudut pandang analisa sistem dan struktural, terlihat terjadi perbedaan diantara kedua negara tersebut terutama dilihat dari efektifitas fungsi input dan output kebijakan yang dirumuskan.

Afrika Selatan yang dinilai oleh dunia internasional sebagai model penerapan kebenaran dan rekonsiliasi dapat melihat masa depan demokrasinya lebih baik dibandingkan dengan Indonesia. Sebab, mekanisme yang disepakati oleh rakyat kebanyakan di Afrika Selatan telah dilalui dan dianggap berhasil mengungkap sebagian besar kasus-kasus pelanggaran HAM di masa rezim apartheid. Meskipun masih didominasi oleh elit otoriter, dukungan sistem dan struktural menjadi penentu berjalannya proses penegakan keadilan transisional di Afrika Selatan.

Sedangkan di Indonesia, masalah keadilan transisional ini tiap tahunnya masih menjadi batu sandungan demokrasi di Indonesia. Pasca digugurkannya UU KKR oleh MK pada tahun 2006, pemerintah sama sekali abai dengan tuntutan dari rakyat untuk 
tetap mengimplementasikan keadilan transisional dalam bentuk kebijakan yang dinilai lebih adil dan rasional bagi semua kalangan. Terhitung telah terjadi lima kali pergantian suksesi kepemimpinan dari era Habibie hingga Joko Widodo saat ini, namun upaya untuk menegakkan keadilan atas berbagai kejahatan politik dan pelanggaran HAM di masa lalu masih belum menunjukkan titik terang. Orang-orang yang menjadi elit pada masa rezim otoriter Soeharto hingga saat ini juga masih banyak yang duduk di dalam sistem dan struktur politik negara.

Apakah dalam hal ini telah terjadi impunitas? Jika benar demikian, maka transisi politik yang sedang dituju seperti yang dikatakan oleh Przeworski, berada dalam ketidakpastian. Sistem politik dapat berjalan demokratis jika terjadi pengefektifan fungsi politik sebagaimana mestinya. Namun sebaliknya, sistem politik dapat juga kembali kepada rezim sebelumnya jika permasalaham tersebut tetap tak ada penyelesaian yang jelas dan terus menumpuk menjadi sebuah fenomena gunung es.

\section{Daftar Pustaka}

Bronkhorst, Daan, Menguak Masa Lalu, Merenda Masa Depan: Refleksi Atas Pengalaman Komisi Kebenaran di Berbagai Negara. Jakarta: ELSAM, 2001.

Chilcote, Ronald, H., Theories of Comparative Politics: The Search of Paradigm. Colorado: Westview Press, 1981.

Hayner, Priscilla B., Setelah Otoritarianisme Berlalu. Jakarta: ELSAM, 2001.

Huntington, Samuel, P., Gelombang Demokratisasi Ketiga. Jakarta: Grafiti. 1995. 


\section{Global Insight Journal}

Vol 01, No. 02

Oktober-Maret 2017

ISSN 2541-318X

Merkel, Wolfgang. Demokrasi di Asia: Sebuah Benua Antara Diktator dan Demokrasi. Jakarta: Fredrich Ebert Stiftung, 2003.

O’Donnell, Guillermo dan Schmitter, Philippe, C., Transition from Authoritarian Rule: Tentative Conclusions about Uncertain Democracies. Baltimore: John Hopkins University Press, 1986.

O’Donnell, Guillermo, C., Philippe, Schmitter, dan Whitehead, Laurence. Transisi Menuju Demokrasi : Tinjauan Berbagai Perspektif. Jakarta: LP3ES, 1993.

Robet, Robertus, Politik Hak Asasi Manusia dan Transisi di Indonesia: Sebuah Tinjuan Kritis. Jakarta: ELSAM, 2008.

Teitel, Ruti G., Keadilan Transisional: Sebuah Tinjauan Komprehensif. Jakarta: ELSAM, 2004.

Teresa, Birks, Tugas yang Diabaikan: Menyediakan Reparasi Komprehensif bagi Korban Persekusi (Kekerasan) Negara 1965 di Indonesia. New York: ICTJ, 2006.

Uhlin, Anders, Oposisi Berserak: Arus Deras Gelombang Demokratisasi Ketiga di Indonesia. Bandung: Penerbit Mizan, 1998.

Makalah: 
Kasim, Ifdhal, Mengapa Komisi Kebenaran dan Rekonsiliasi Diperlukan?. Makalah yang diterbitkan oleh lembaga ELSAM tahun 2002.

Laporan Bersama ICTJ dan Kontras, Keluar Jalur: Keadilan Transisi di Indonesia Setelah Jatuhnya Soeharto. Maret 2011.

Memastikan Agenda Negara Dalam Menyelesaikan Pelanggaran HAM Masa Lalu. Sebuah Kertas kerja yang diterbitkan oleh lembaga ELSAM pada tahun 2012.

Soeprapto, Enny, Keadilan Transisional: Masih relevankah Sebelas Tahun Reformasi? Makalah yang disampaikan pada Komisi Nasional Hak Asasi Manusia (Komnas HAM) tanggal 19 Februari 2009 